\title{
Tourism Workers in Asean Economic Community: Opportunities or Challenges?
}

\author{
E. S. Nurdin \\ Universitas Pendidikan Indonesia \\ encep.sn@upi.edu
}

\author{
T. Kartika \\ STIEPAR YAPARI-AKTRIPA Bandung \\ nengtiting_kartika@yahoo.co.id
}

\begin{abstract}
At the moment tourism has a very important role for the life of the economic world. Along with its development, the need for professionals in tourism field is increasing. Ahead of the implementation of the Asean Economic Community (AEC) in 2015, the challenge in the field of tourism that must be faced is to prepare Indonesian professional workforce that skilled, intelligent, and competitive. AEC is a form of economic integration in ASEAN to face free trade among countries in ASEAN. Preparation of labor refers ASEAN Common Competency Standards for Tourism Professionals and the ASEAN MRATP (Mutual Recognition Arrangement on Tourism Professionals) which is designed to enable the mobility of employment for skilled tourism labor within each member state and has the skills and qualifications of working tourism professionals from different ASEAN countries. In facing these challenges, the government agencies such as the Tourism and Culture Board has an important role in making policy on tourism development. The locus of this research is the Culture and Tourism Board Bandung City with descriptive qualitative research approach. This research refers to the local regulation No. 13 Year 2007 on Tasks and Functions of the Department of Culture and Tourism Bandung which carry out most of affairs of the region in the field of culture and tourism. The results of study showed that in order to answer the challenges of professional work in tourism ahead of the Asean Economic Community synergy of several parties that is not only the governments, but also from the tourism industry, tourism agencies, academician and community is required.
\end{abstract}

Keywords: Tourism Workers; Opportunities and Challenges, Asean Economic Community

\section{INTRODUCTION}

In the framework of the ASEAN Economic Community (AEC) in 2015, the government continues to make preparations in order to increase the human resource competitiveness of Indonesia. At this time the tourism sector has a very important role in economic growth both nationally and globally. In the scope of ASEAN, Pitana (2015) explains that the growth of ASEAN tourism sector is the highest in the world, over the period 2005-2012 grew at an average $8.3 \%$ per year, or more than average global tourism growth of only 3.6\% per year. Even in 2013 the flow of tourists to ASEAN countries has reached 92.7 million, an increase of $12 \%$ compared to the previous year, while the global growth of only 5\% [1]. Increased growth in the ASEAN tourism sector created opportunities for tourism employees to work in the region, so that it will provide its own competition among foreign workers in terms of having job opportunities in ASEAN countries.

According to the result of study conducted by Benny and Abdullah in several regions in Indonesia (2011) showed that there was a positive attitude toward perceived benefits of the Asean Community. In other word, there was a high level of awareness and understanding of Asean on the part of the Asean community [2]. This condition brings into positive response to Indonesian workers in facing the tourism challenging $\mathrm{n}$ global context.

The next challenging aspect is the quality of skilled manpower in the tourism sector performance in welcoming AEC 2015. According to World Bank Report, there is a big gap in the quality of skilled manpower in Indonesia. The biggest gap is the use of a foreign language (44\%), use of a computer (36\%), behavioral skills (30\%), critical thinking skills (33\%) and in basic skills (30\%). The worse condition is the imbalance of the number of workers in Indonesia who have higher education only 7\% [3].

Besides the human resources challenges, there are certainly opportunities that we can get in welcoming of AEC 2015. Indonesia has big motivation and move to be more competitive in producing the skilled labor in the field of tourism. The workers in the field of tourism sector in Indonesia tend to be ready to face the EAC that will be effective eat the end of 2015. The readiness of workers in this sector have a workforce that is skilled and competent as well as the carrying capacity of the government to provide education and training, and profession certification, so that they have a guaranteed ability to work in the tourism sector.

Regarding to the tourism human resource development facing AEC 2015, Indonesia both central and local governments jointly implement some programs to produce a professional workforce and able to meet the needs of the industry. AEC is a form of economic integration of ASEAN region in the era of free trade among countries in ASEAN. This is done to maintain political stability and regional security ASEAN, enhance the overall competitiveness of the region on the world market, and boost economic growth, reduce poverty, and improve people's lives. Through MEA, it will create a huge market in region of ASEAN and give impact on the economy development.

To anticipate the global challenges, the government of Indonesia did the legalization of tourism of the Indonesian 
Presidential Regulation 2 of 2007 dated 25 January 2007 on the ASEAN Tourism Agreement. In Article 8 [4] states that Member States shall cooperate in the development of human resources in the tourism industry by: 1 . Formulate settings without barriers to enable ASEAN countries to use professional tourism experts and skilled labor in the ASEAN region based on bilateral arrangements, 2 . Intensify the sharing of resources and facilities for tourism education and training programs, curriculum and skills 3 . Increasing tourism and formulate competency standards and certification procedures on skills and the qualification in the ASEAN region, 4. Strengthen public-private partnerships in developing the company's human resources, and 5. Conduct cooperation with other countries, groups of countries and present international institutions in the development of human resources in the field of tourism.

While the ASEAN countries should also be prepared to face the enactment ASEAN Mutual Recognition Arrangement (MRA) 2015 in 2015 that include: 1. facilitating the mobility of professionals in tourism, 2. exchanging of information on best practice in the field of education and competency-based training for professionals. To address this set ASEAN Common Competency Standards for Tourism Professionals (ACCSTP). This ACCSTP refers to the minimum requirement of the standard of competence in the field of hotel and travel services aimed at improving tourism services and facilitate the development of the MRA between the member countries of ASEAN. To reinforce that the Government of Indonesia through Law No. 10 of 2009 on Tourism, all workers in the field of tourism shall have standard of competence.

To implement the government policy, then it cannot be separated from the role of local governments. This research was conducted at the Culture and Tourism Board Bandung city to study the extent to which the role of agencies in an effort to improve the tourism professionals ahead the AEC.

\section{METHODOLOGY}

The methodology used in this research is descriptive qualitative. Nazir states that the purpose of the descriptive research is to gather detailed information describing actual symptoms [5]. Whereas qualitative data is a form of presentation discussed how the researchers' analyzed data collected in the study

The necessary data in this study are primary and secondary data. According to Nazir (2003) the primary data is data that is directly obtained or collected directly in the field by a team of researchers [5]. While the secondary data is data obtained or collected by the person who conducted a study of the resources that already exist. This data can be obtained from the library or the reports of previous studies. Secondary data is also referred to as data is available. In this study, observation and interviews were conducted to related parties, especially in Culture and Tourism Board of Bandung city.

\section{RESULT AND DISCUSSION}

\section{A. Bandung and Tourism}

Tourism is one of the leading sectors in the city of Bandung and gives a significant contribution to the economy of the city of Bandung. Bandung tourism development is supported by the availability and variety of urban tourism products in the form of various features of the city, both primary and secondary elements such as: knowledge, history, culture, heritage, culinary, shopping and others. Bandung is currently dominated by the activities of shopping; especially with the development of factory outlets. In line with the function of Bandung as the capital of West Java province and city services, tourism product MICE (Meeting, Incentive, Conference, Exhibition), and tourism-based education are also the top tourist area refers to RPJMD Bandung City [6]

The number of tourist arrivals Bandung city during the period 2009-2011 increased sharply. Based on the data of Culture and Tourism Board City of Bandung, 2014, the biggest jump occurred in 2009-2010. If in 2009 the number of tourists that there were $3,096,869$, tourists in 2010 rose sharply to $3,205,269$. The increase in the number of tourists also occurred in 2011, but declined in 2012 to as many as 3,326,125 tourists [7].

TABLE I. NUMBER OF TOURIST ARRIVALS TO BANDUNG CITY2009-2013

\begin{tabular}{|l|l|l|l|}
\hline Year & Number of Visit \\
\hline & Domestic & Abroad & Total \\
\hline 2009 & 2.096 .869 & 168.712 & 3.096 .869 \\
\hline 2010 & 3.024 .666 & 180.603 & 3.205 .269 \\
\hline 2011 & 3.882 .010 & 194.062 & 4.076 .072 \\
\hline 2012 & 3.175 .662 & 150.363 & 3.326 .125 \\
\hline 2013 & 3.726 .447 & 170.982 & 3.897 .429 \\
\hline \multicolumn{4}{|c|}{ a. Source: Culture and Tourism Board Bandung City, 2014 }
\end{tabular}

\section{B. The Role of Culture and Tourism Board}

The efforts to improve human resources in tourism cannot be separated from the central government policy in coordination with the provincial government and the government of the policies made is very important since it affects the implementation.

As explained by Anuar (2013) that the policy could be made at the national level, followed by the next policy and implemtation strategies at the state level, so that each lne of tourism development is as planned [8]

According to Edward III (1980) the study of implementation is crucial for the study of public administration and public policy [9]. Policy implementation, as we have seen, is the stage of policy making between the establishment of a policy and the consequences of the policy for the people whom it affects.

Moreover, Edward [9] states that there are four critical factors or variables in implementing public policy: communication, resources, dispositions or attitudes, and bureaucratic structure. A side from directly affecting implementation, however, they also indirectly affect it through their impact on each other. In other words, communication affects resources, dispositions, and bureaucratic structures, which in turn influence implementation. It can be illustrated as follow: 


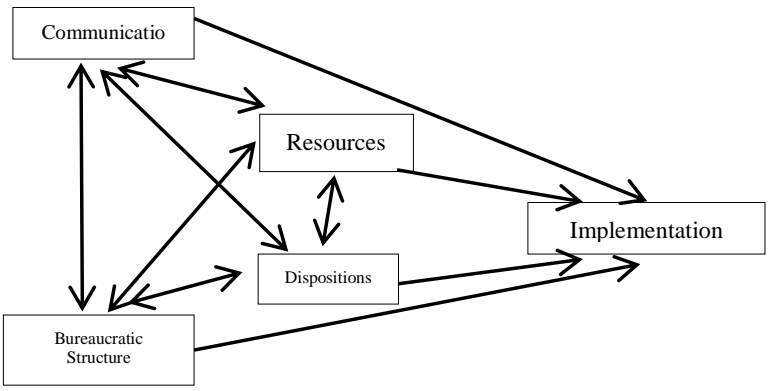

b. Source: Edwards III, 1980:148

Fig. 1. Direct and Indirect Impacts on Implementation

As well as on government policy of the Republic of Indonesia in order to enhance human resources has been stated in both its legal basis Law, government regulation, as well as regional regulations. The scheme can be seen in the following figure.

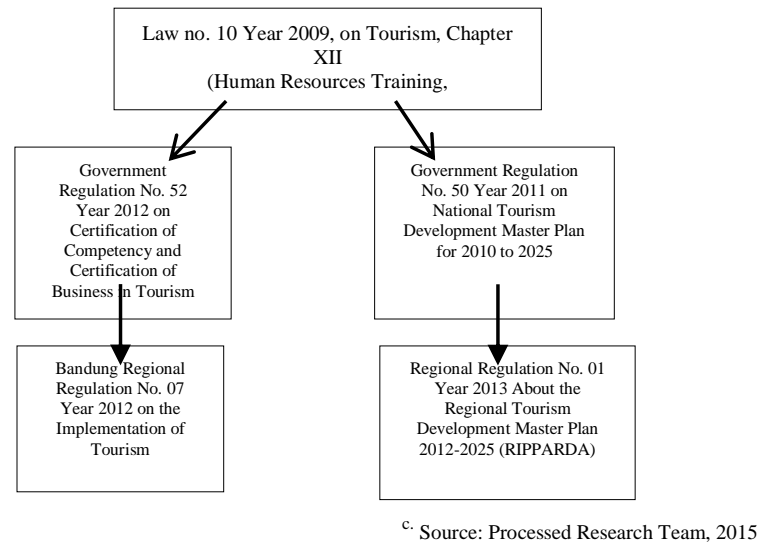

Fig. 2. Legal Base of Tourism Human Resource Development

In the division of government affairs has been stipulated in Government Regulation No. 38 of 2007 between government, provincial governments, and the Local government district / city is divided into two parts, namely the obligatory functions and affairs of choice. Referring to these rules are part of the business tourism options. Affair option referred to in this context is a matter which obviously exists and has the potential to improve the welfare of the community in accordance with the conditions, uniqueness, and potency

Referring to regulation 13 of 2007 , duties and functions of Culture and Tourism Bandung is as follows: Department of Culture and Tourism has a fundamental duty to implement part of affairs of the region in the field of culture and tourism. To carry out basic tasks as mentioned above, the Culture and Tourism board has the function:

- Formulation of technical policy fields of culture and tourism;

- Implementation of government affairs and public services field of culture and tourism;

- Development and implementation of tasks in the field of culture and tourism which includes culture and arts, tourism facilities, attractions and tourism marketing;

- Implementation of administrative technical services department;

- Implementation of other duties assigned by the mayor in accordance with its duties and functions.

In an effort to increase human resources quality, the local government in this case the city government as stipulated in the Regulation of Bandung Number 07 of 2012 on the implementation of the tourism Chapter X of Article 56 that the local government training tourism human resources in accordance with the legislation. Further described in Article 57 paragraph (1) that the workforce in the field of tourism has standards of competency.

As the result of interview and literature study, there are some activities organized by culture and tourism board city of Bandung in improving the quality of human resources in the field of tourism among the various training for the tourism industry, such as training for a song guide, bartenders, spa, technical guidance, socialization, as well as guidance to the industry players. One of the government's roles is to ensure that within the provincial government and across all levels of government there is coordination and clarity in roles and responsibilities [10].

\section{TOURISM PROFESSIONAL COMPETENCY}

In order to improve the working professional in the field of tourism, the government through the Tourism Act 10 of 2009 on Chapter XII of Article 52 that the Government and the Local Government training tourism human resources in accordance with the legislation.

The importance of competency certification for workers engaged in the tourism industry has been regulated in the Law on Tourism of Indonesia, namely Law No. 10 of 2009 which states Certification is the process of granting certificates to business and tourism workers to support the improvement of the quality of tourism products, services, and management of tourism. While Competence can be defined set of knowledge, skills and behaviors that must be owned, lived, and dominated by tourism professionals to develop the professional work.

The Article 26 of Law No. 10, 2009 states that any tourism entrepreneurs are obliged to increase the competence of workers through training and education and applying business standards and competency standards in accordance with the provisions of the legislation. This means that an increase in the competence of the workforce in order to obtain competency certification is an obligation of the employer itself. But if we look, employers are less concerned about the increase in human resources. They prefer to invest the funds held in the building / physical, because they do not directly see the benefits of the certificate of competency. Other settings of Standardization and Certification of competence can also be seen in Article 53 which states that the workforce in the field of tourism has competency standards. As stipulated by Article 55 of Law Number 10 Year 2009 on Tourism (about further regulation of certification of competence) 
and to meet the challenges ahead, the Government Regulation on Certification of Competency and Certification of Business in Tourism Government Regulation No. 52 Year 2012 on Certification of Competence in the Field of Tourism.

Facilitating the implementation of this competency certification is mandated Act No. 10 of 2009 on Tourism and set forth in the strategic plan of the Ministry of Tourism and Creative Economy, 2012. From 2007 to 2014, The Misnistry of Tourism has conducted the certification program as much as 64127 workers in tourism among other fields of hotel and restaurant, spa, travel agencies, MICE, tour leader, catering services, as well as special interest tourism such as rafting and diving. The number of workers who have received this certification is well above the target set at the end of 2014 as many as fifty thousand tourism workforce. [11]

For ASEAN, to apply professional standards in tourism regulated in the ASEAN Mutual Recognition Arrangement on Tourism Professionals (MRA-TP). MRA$\mathrm{TP}$ is designed to enable the mobility of tourism employment for skilled labor within each Member State and to recognize the skills and qualifications of tourism professionals working from different ASEAN countries. The MRA - TP aims to facilitate mobility of tourism professionals within ASEAN based on competence-based tourism qualifications or certificates, and at the same time, improve the quality of services delivered by tourism professionals.

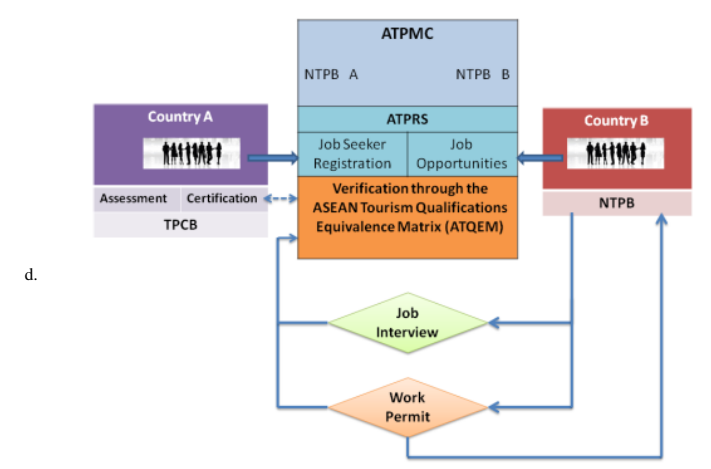

Source: Guide To MRA-TP, 2012

Fig. 3. Key Element of MRA-TP

Some terms are explained as follow:

- The ASEAN Tourism Professional Monitoring Committee (ATPMC) consists of ASEAN NTOs and appointed representatives from the National Tourism Professional Boards (NTPBs);

- The ASEAN Tourism Professional Registration System (ATPRS) is a web-based facility to disseminate details of certified Foreign Tourism Professionals within ASEAN. This registration system is still under development and will be launched in 2015;

- The National Tourism Professional Board (NTPB) refers to the Board for Tourism Professionals composed of representatives from the public and private sectors (including academia and other relevant tourism stakeholders) to be determined by the respective ASEAN NTOs;
- The Tourism Professional Certification Board (TPCB) refers to the government board and/or agency authorized by the government of each ASEAN Member State primarily responsible for the assessment and certification of Tourism Professionals;

According to MRA guide the tourism professional refers to a natural person who holds the nationality of an ASEAN Member State certified by the TCPB. Meanwhile TPCB (Tourism Professional Certification Board) refers to the government board and/or agency authorized by the government of each ASEAN Member State primarily responsible for the assessment and certification of Tourism Professionals. The competent worker consists of three elements that should be completed: Skill, Attitude, Knowledge as figured out below:

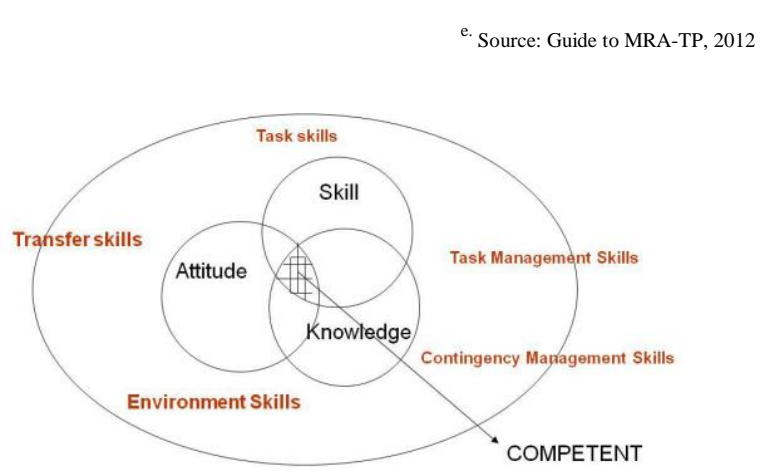

Fig. 4. Competent Worker

MRA actually brings some benefits for governments in ensuring commitment and agreement to international trade, and encourage the sharing of good practice and information between partners. Meanwhile for tourism professionals and the industry, MRAs provide the following benefits to facilitate mobility of tourism professionals based on the tourism competency qualification/ certificate, enhance conformity of competency based training/education, recognize skills of tourism professionals, improve the quality of tourism human resources (graduates are ready to work in the industry), and enhance the quality of tourism services. For education and training providers, MRAs provide the following benefits as a clear set of standards for development of training programs, a competency-based training and assessment system for preparing trainees for the tourism industry, a range of job-based tourism qualifications based on common labor divisions, and an opportunity to become one of the preferred education and training providers for the range of ACCSTP qualifications. The ACCSTP are based on the concept of competency the knowledge, skills attitudes (KSA) that individuals must have, or must acquire, to perform effectively at work. [12] 


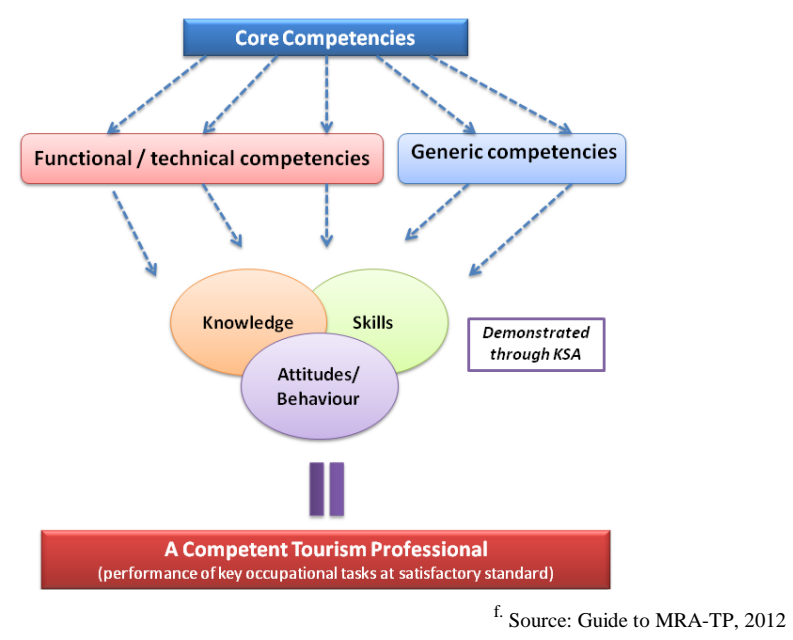

Fig. 5. Competency Framework

\section{CONCLUSION}

From the results of this study concluded that the government, particularly the Culture and Tourism board has participated in the effort improving tourism professionals through several of programs such as conducting training, supervision, socialization and training for the tourism industry. Those programs conducted refer to the policy in Indonesia. The activities carried out in the form of training, socialization, supervision as a step towards certification of competence will be conducted by an independent board.

Certification of competency is an effort to provide legal protection for Indonesian workers in facing of AEC 2015 through standardization and certification. The method is expected to be more optimal for Indonesian tourism management. The importance of competency certification for workers engaged in the tourism industry has been regulated in the Law on Tourism of Indonesia, namely Law No. 10 of 2009 which states Certification is the process of granting certificates to business and tourism workers to support the improvement of the quality of tourism products, services, and management of tourism. While Competence can be defined set of knowledge, skills and behaviors that must be owned, lived, and dominated by tourism professionals. The competence certification is needed in the face of labor competition in national and international levels.

To answer the challenge of working professionals in the field of tourism ahead of the ASEAN economic community needed the synergy of several parties that not only governments, but also from the tourism industry, tourism agencies, academician and the society. The awareness of the industry and the community to improve the working professional is needed while academics (tourism school) is preparing the curriculum so that the graduates have the tourism standard competency.

\section{REFERENCES}

[1] Pitana. Koran Jakarta. "Sektor Pariwisata Siap Hadapi MEA 2015". http://www.koran jakarta.com.2014. Accessed 20 September 2015

[2] Benny, G. \& Abdullah K. "Indonesian Perception and Attitudes Toward Asean Community". Journal of Current Southeast Asean Affairs I/2011: 39:67

[3] World Bank Report "Human Resources Index", 2013

[4] Indonesian Presidential Regulation 2 of 2007 dated 25 January 2007 on the ASEAN Tourism Agreement

[5] Nazir, M. “Metode Penelitian” Jakarta: Graha Indonesia. 2003

[6] RPJMD Kota Bandung 2014-2018

[7] Culture and Tourism Board City of Bandung, 2014

[8] Annuar, Ahmad, Jusoh, and Hussain, "Policy and Tourism Development Startegy Toward Tourist Friendly Destiation in Kuala Lumpur" Asian Social Science Vo. 9 N0. 2, 2013 Published in Candian Center of Science and Education

[9] Edward III. George C. "Implementing Public Policy”.Congressional Quaterly Press.Washington DC. 1980: 147

[10] Best Practice and Ontario Competitiveness Study Research Papers Review: "Role of Government in Tourism Research Study". February 2009.

[11] The Ministry of Tourism, 2013

[12] Guide to Asean Mutual Recognition Arrangement On Tourism Professionals For Tourism \& Hospitality Organisations Produced by the ESRT Programme for Vietnam National Administration of Tourism (VNAT), Ministry of Culture, Sport and Tourism, on behalf of the Association of Southeast Asian Nations (ASEAN), 2012. 